\section{Vietnam Journal of Agricultural Sciences}

\title{
A Review of Cunninghamia lanceolata (Lamb.) Hook: A Recent Update and Potential Application in Vietnam
}

\author{
Tran Binh Da ${ }^{1}$ \& Le Thi Ngoc $\mathrm{Ha}^{2}$ \\ ${ }^{1}$ Faculty of Agronomy, Vietnam National University of Agriculture, Hanoi 131000 , \\ Vietnam \\ ${ }^{2} \mathrm{PhD}$ student of Vietnamese Academy of Forest Sciences, Hanoi 130500, Vietnam
}

\begin{abstract}
By reviewing worldwide literature, this paper aimed to systematically collate available information about the species Cunninghamia lanceolata. Based on the findings of the review, including the species' floral characteristics; updated distribution; historical knowledge and heritage; growth and factors influencing its forests; soil nutrition and microbes; carbon storage; wood; and chemicals and essential oils, we have identified issues for consideration regarding the use of this species for big timber production in Vietnam. We propose that it is suitable for a range of applications: for small or large timber plantations, mono/mixed plantations, and agroforestry. If planted at lower altitudes or warmer temperatures, its growth is likely to be improved, but seed production may be less successful. Cultivation of this species for big timber production should be undertaken according to silviculture best practices, ensuring good seed quality, a suitable stand density, and appropriate fertilization thinning strategies, in support of government policies and in accordance with current science and technology.
\end{abstract}

\section{Keywords}

C. lanceolata var. lanceolata, C. lanceolata var. konishii, forest, oil, timber

\section{Introduction}

Woody products are always in high demand in worldwide markets and are linked to the forestry sector which exploits timber from both natural and plantation forests. In the context of climate change, sustainable timber production and forest development are increasingly important at both national and global scales. While a recent 'boom' in the wood processing industry in Vietnam is a positive signal for economic development in this sector, it has also highlighted sustainability issues due to the imbalance between timber plantation productivity and processing capacity. Following decades of depletion 
of natural forests, the development of big timber plantations has not been sufficient to keep pace with demand. While about 40 million cubic metres of equivalent round wood volume is required by the processing industry annually (Itto, 2019), timber plantation development has not yet met the target of 290,000 ha (Vietnam Gov, 2017), and only 40,000 cubic metres of legal raw timber is being provided annually by domestic forests (VOV, 2017).

Of the fourteen big trees included in legislation (namely Eucalyptus camaldulensis, Eucalyptus hybrid, Eucalyptus urophylla, Dipterocarpus alatus, Acacia mangium, Acacia auriculiformis, Acacia hybrid, Mangletia conifera, Cunninghamia lanceolata, Hopea odorata, Pinus massoniana, Pinus kesiya, Melaleuca leucadendra, and Melaleuca cajuputi), only six are native species (MARD, 2018), one of which is $C$. lanceolata. However, the current understanding of $C$. lanceolata and other native species for big timber plantations is seriously limited.

Before the 1990s, a large area of natural $C$. lanceolata was explored for big timber in the Northern regions of Vietnam, but growers and researchers were not interested in this species. As such, research results and published literature regarding C. lanceolata are very poor. Therefore, this review has investigated worldwide literature to systematically collate information that will significantly improve the understanding of this species for study, research, and its application for timber production in Vietnam.

\section{Worldwide overview}

\section{Classification of C. lanceolata}

Commonly called Chinese fir in English, this species is currently distributed naturally in the sub-tropical regions of China. Older records indicate that it was previously also naturally occurring in Vietnam and Laos, and refer to it with the scientific names Cunninghamia lanceolata (Lamb.) Hook. (Wcsp, 1827), Cunninghamia konishii (Wcsp, 1908), and Cunninghamia lanceolata var. konishii (Wcsp, 1932). Karyotype tests revealed that
Cunninghamia konishii, Cunninghamia lanceolata, and Taiwania cryptomerioides were all members of Taxodiaceae (Schlarbaum \& Tsuchiya, 1984; Chung et al., 2004). In Vietnam, it is called "Samoc" or "Samu" and currently exists in two varieties, namely $C$. lanceolata (Lamb.) Hook. var. lanceolata and C. lanceolata (Lamb.) Hook. var. konishii (Hayata) Fujita (Pham et al., 2013). Particularly, $C$. lanceolata var. konishii was recently reviewed and recorded as one of 33 species, 2 subspecies, and 5 varieties of native conifers belonging to 5 families and 19 genera found in Vietnam (Phan et al., 2017).

\section{Distribution and adaptation to climate change of C. lanceolata}

Recently, Chinese fir was recorded occurring as an introduced plant in many countries around the world (Figure 1), and used mostly for landscaping and horticulture. Outside of China, there are several academic records concerning this species with regard to commercial plantations (e.g. in New Zealand (Fung, 1993b; Fung, 1993a); and in Brazil (Heinsdijk, 1972; Wadsworth, 1997)).

In Vietnam, natural populations of $C$. lanceolata var. konishii were previously found at Tay Con Linh in Ha Giang Province, Xuan Lien in Thanh Hoa Province, and Pu Hoat, Phu Huong, and $\mathrm{Pu}$ Mat in Nghe An Province (Vietnam Plant Data Center, 2009).

To determine whether the distribution and productivity of $C$. lanceolata is being affected as a result of climate change, the research team of Lu et al. (2015) applied process-based growth models to predict its distribution and productivity. The results indicated a northward shift from the tree's current range. The growth model also revealed minor increases in productivity in some of the existing distribution areas, particularly in central China, and attributed this to the warmer climate (Lu et al., 2015). Other similar results also suggest that climate change will lead to a modest increase in long-term stem wood biomass production $(6.1 \%$ to $12.1 \%$ increase after 30 to 60 years). Thus, climate change could have a positive impact because of both a lengthening of the growing season and an 


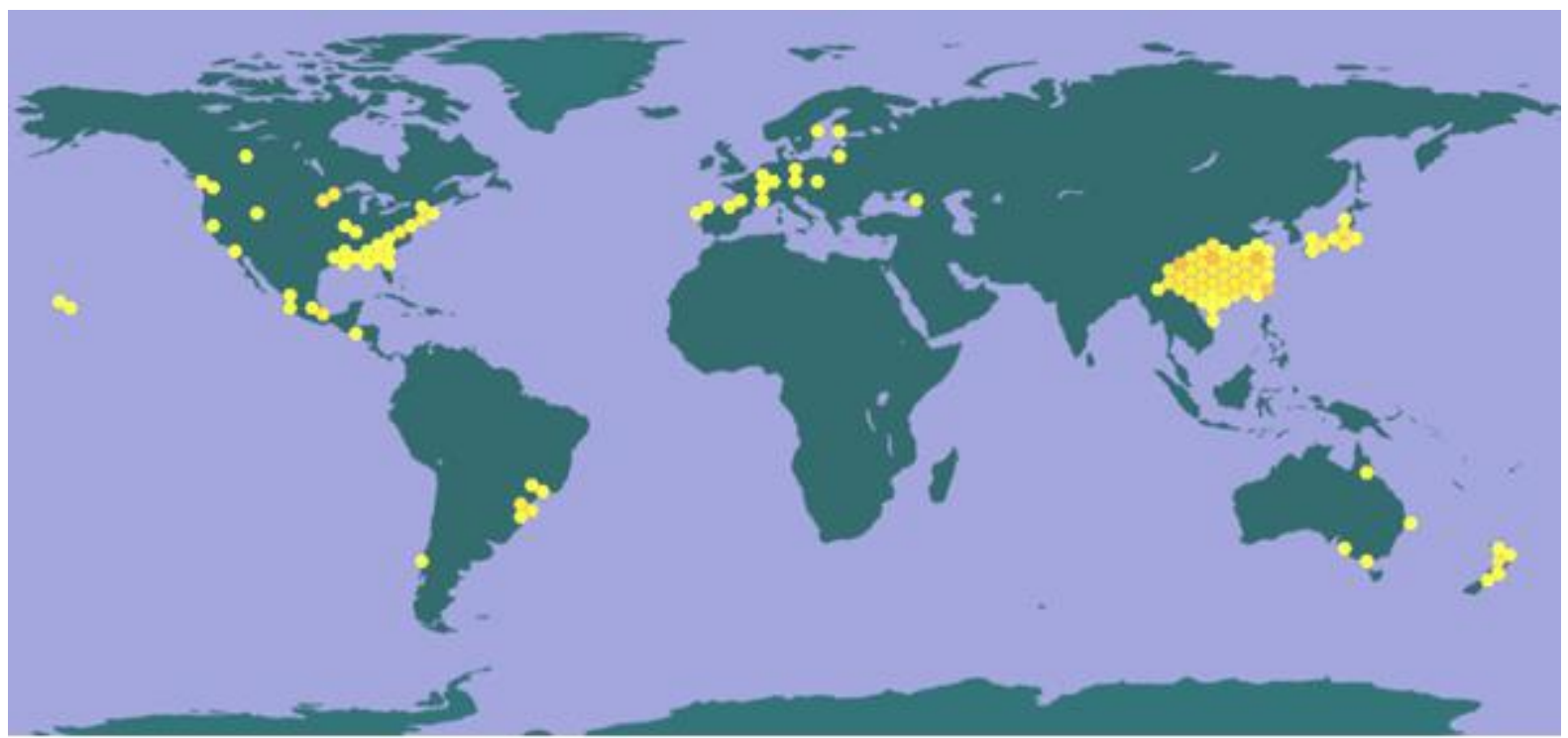

Figure 1. Distribution map of $C$. lanceolata around the world Source: Farjon (2010)

increase in nutrient-cycling rates, likely contributing to the increasing growth rate of the species' trees (Kang et al., 2017).

\section{History and heritage of C. Ianceolata}

Open-pollinated seeds were tested for allozyme polymorphisms at 24 loci to assess the genetic diversity and multilocus associations in 16 populations of $C$. lanceolata. The results revealed that population subdivision, the founder effect, occurrences across diverse environments, a mating system dominated by inbreeding, and historical events from 2000 years of cultivation in China were likely factors in the generation and maintenance of the multilocus genetic structure in this conifer species (Yeh et al., 1994).

A record indicated that traditional Chinese afforestation and reforestation systems using $C$. lanceolata seedlings grown from rooted cuttings have been widely implemented for at least 800 years. In addition, vast local knowledge of how best to grow this species has been passed down through many generations, establishing successful methods of extensive site preparation, wide spacing, interplanting with crops, planting in mosaics of small-family or clonal blocks, small-block clear-cut harvesting, and regenerating with cuttings, stecklings, and stump sprouts (Minghe \& Ritchie, 1999).

In Vietnam, C. lanceolata var. konishii grows naturally in Pu Hoat Nature Reserve, Nghe An Province, located at 19052' N, 104056' E (Nguyen Danh Hung et al., 2017). Here there are still existing populations with very big trunks, including one Heritage Tree recorded with a diameter at breast height (DBH) of $540 \mathrm{~cm}$ and a height of $70 \mathrm{~m}$, estimated to be about 2000 years old (Nguyen Dinh Vo, 2017).

\section{Growth and factors affecting C. Lanceolata forests}

Worldwide, dozens of literature articles have been published in English, recording the results of studies on the growth and factors impacting C. lanceolata plantations/forests undertaken by Chinese scientists. A study on the early regeneration stages of two major coniferous species ( $P$. massoniana and $C$. lanceolata) in a secondary mixed coniferous plantation explained that $C$. lanceolata was likely to deliver better growth of the main stem when it was shaded (Cheng et al., 2011). Furthermore, a report indicated that the germination of $C$. lanceolata seeds is poor in natural regeneration, possibly due to low light and a thick litter layer. Research to investigate how to improve the species' natural 
regeneration capacity revealed that seedling emergence was highest at 5-15\% sunlight, whereas seedling height, root length, root mass, stem mass, leaf mass, and total mass were greatest at $60 \%$ sunlight and that thinning significantly increased the success of natural regeneration (Liu et al., 2018).

In natural ecosystems, many factors interact to impact individual or/and populations of plants. Dozens of studies have been conducted to investigate the factors influencing $C$. lanceolata forests. First, increased mean temperatures were shown to promote better growth performance of C. lanceolata populations, which then exhibited the greatest germination capacity. C. lanceolata within the southern population were better adapted to extremely high temperatures than specimens from the northern region population (Zhou et al., 2016). Second, topography influenced the dominant stand height of $C$. lanceolata, with elevation being the most significant factor, followed by soil type, aspect, and slope (Zhu et al., 2019). Third, the structural characteristics of the tree crowns of $C$. lanceolata were such that leaf biomass increased with the crown thickness (Xu et al., 2019), and that related to thinning due to the effects of photosynthesis which is dependent on needleleaf age ( $\mathrm{Li}$ et al., 2017). The self-thinning exponents of $C$. lanceolata changed systematically with the mortality rate classes, and -1.5 was a transitory value in the course of self-thinning (Sun et al., 2011). The self-thinning exponent of organs was estimated to be 1.42 for stems, 0.93 for branches, 0.96 for leaves, 1.35 for roots, and 1.28 for shoots, indicating that the thinning exponents of trees, branches, leaves and roots of $C$. lanceolata were significantly lower than 3/2 (Xue et al., 2015). Tree mortality, related to the thinning of trees, is an important process during forest succession, influencing forest structure, composition, and ecosystem services. One study showed that the age and structure variables had a much larger impact on mortality $(88.82 \%)$ than climate variables (11.18\%) (Zhang et al., 2020). However, $C$. lanceolata tree growth rates did not respond to pruning, understory removal, or their interactions. In addition, foliar photosynthesis did not exhibit changes following understory removal in either pruned or unpruned stands $(\mathrm{Li}$ et al., 2020). Last, the model results of Bi et al. (2007) suggested that yield decline is caused primarily by a decline in soil fertility, largely as a consequence of slash burning in conjunction with short rotations. Importantly, another study indicated that mixed $C$. lanceolata plantations could improve the soil quality, especially for chemical properties (Zhou et al., 2020)

Regarding growth ring width, $C$. lanceolata is a rapid growth species, therefore, a study of the molecular mechanisms underlying growth alteration due to vascular cambium activity indicated that various cambium-related molecular activities result in alterations in the growth of $C$. lanceolata, particularly during the transition from juvenile to mature stages ( $\mathrm{Xu}$ et $a l ., 2016$ ). Furthermore, the average growth ring width of $C$. lanceolata was in inverse proportion to the density, modulus of elasticity (MOE), and modulus of rupture (MOR) of the dimension of the lumber (Jiang et al., 2010).

\section{Soil nutrition and microbial of C. Lanceolata forests}

The results of He et al. (2007) showed that after a native broadleaved forest was replaced by a mono-cultured $C$. lanceolata plantation, the soil microbial biomass and nutrient pool decreased significantly due to less litter and a slower decay rate associated with human disturbance. The mean annual litter production of monoculture $C$. lanceolata stands was significantly (24\%) lower than mixed stands of C. lanceolata and M. macclurei (Wang et al., 2008). However, there was no significant difference in litter decomposition rates between these different habitats (Wang et al., 2009). Other results showed that successive rotations of C. lanceolata notably decreased the quantity of total soil organic carbon (SOC), recalcitrant fraction, carbohydrates, and microbial properties, especially at the $0-10 \mathrm{~cm}$ horizon (Zhang et al., 2009). With $C$. lanceolata plantations aged 10, 22, and 34 years, annual litterfall production increased with stand age and was $\quad 3.29( \pm 0.36), \quad 3.73( \pm 0.21), \quad$ and $4.88( \pm 0.21)$ tons $\mathrm{ha}^{-1} \mathrm{a}^{-1}$, respectively. 
Generally, the annual total nutrient return to the soil was in the order of 1.12-2.71 tons $\mathrm{ha}^{-1} \mathrm{a}^{-1}$ for calcium (C), 39.32-62.04 $\mathrm{kg} \mathrm{ha}^{-1} \mathrm{a}^{-1}$ for nitrogen (N), 15.95-22.44 kg ha-1 $\mathrm{a}^{-1}$ for potassium $(\mathrm{K})$, and $1.30-1.63 \mathrm{~kg} \mathrm{ha}^{-1} \mathrm{a}^{-1}$ for phosphorus (P) (Zhou et al., 2015). In addition, soil nutrition changed from N-limiting to P-limiting conditions, and the nutrient-use strategy changed from "conservative consumption" to "resource spending" of plantations at the ages of 3, 8-11, 16, 20, 25, 29, and 32 years (Wu et al., 2020).

Forest biomass was used as a proxy for soil conditions. One study explained the negative relationships between the cyclic dipeptide concentration, microbial community composition, and root biomass (Xia et al., 2015). Similarly, another study showed that the fine root biomass of trees and understory vegetation were significantly and negatively correlated with forest biomass, but the results clearly demonstrated that fine tree root biomass was significantly promoted and increased due to competition from understory vegetation where forest biomass is low (Liao et al., 2019). Furthermore, understory vegetation had more influence on the microbial activities than on the substrate affinities of extracellular hydrolases. Microbes tended to concentrate on maintaining catalytic efficiency when the SOC contents were between 15.8 and $20.3 \mathrm{~g} \mathrm{~kg}^{-1}$ and when the understory vegetation was removed, but the catalytic efficiency could decrease under extremely low soil C content. So, understory vegetation should be maintained to sustain the potential microbial activity in $C$. lanceolata forests (Yang et al., 2019). On the other hand, warming and $\mathrm{N}$ deposition were important aspects of environmental change affecting plants, microbes, and soil processes, thus warming, regardless of $\mathrm{N}$ addition, significantly decreased arbuscular mycorrhizal (AM) fungal diversity and altered AM fungal community composition, while a $\mathrm{N}$ addition alone had only minor effects (Cao et al., 2020).

\section{Carbon storage of C. Lanceolata forests}

Tree plantations contribute towards balancing global carbon and nitrogen cycles, so large plantations of $C$. lanceolata could have an important role in mitigating climate change. Carbon accumulation and distribution conducted on a 13-year-old mixed plantation of $P$. massoniana and $C$. lanceolata showed that the annual net productivity of the mixed plantation was $11.46 \mathrm{t} \mathrm{hm}^{-2} \mathrm{a}^{-1}$, and that of sequestered carbon was $5.96 \mathrm{t} \mathrm{hm}^{-2} \mathrm{a}^{-1}$, which was equivalent to fixing carbon dioxide (CO2) of $21.88 \mathrm{t} \mathrm{hm}^{-2} \mathrm{a}^{-}$ 1 (Kang et al., 2006). With a 22-year-old $C$. lanceolata plantation, carbon stored both aboveand below-ground was 154.3 tons $\mathrm{hm}^{-2}$, and most of the carbon was in the soil pool (accounting for $55.2 \%$ ) (Niu et al., 2009). Other results showed about $35-45 \%$ of equivalent SOC stocks in the upper soil layer $(0-20 \mathrm{~cm})$ in stands of all ages, indicating more organic carbon accumulation in the surface layer compared to subsurface layers (> 20cm) (Selvaraj et al., 2017). Comparing $C$. lanceolata plantations (23-32-year-old) with evergreen broadleaved forests (40-100-year-old), soil carbon stocks showed no variation, but in younger $C$. lanceolata plantations carbon stocks were much less (Chen et al., 2017). Annual carbon return to soil was $1.12-2.71$ tons $\mathrm{ha}^{-1} \mathrm{a}^{-1}$ (Zhou et al., 2015). Moreover, other papers' results highlighted that understory removal in thinned stands did not exacerbate soil carbon emission within the plantation (Li et al., 2019a), while the response of heterotrophic (Rh) and autotrophic ( $\mathrm{Ra}$ ) components of soil respiration (Rs) to fertilization was important to evaluate the effects of management practices on soil carbon cycling within young $C$. lanceolata plantations (Wang et al., 2017).

\section{Wood study of C. lanceolata}

A study of the mechanical and physical wood properties of New Zealand-grown $C$. lanceolata showed the tree's dimensional stability, ease of drying, and reputed durability could allow it to be used in applications such as weatherboarding, paneling, and joinery (Fung, 1993b). Another study on the pattern of variation of wood properties of natural $C$. lanceolata suggested that the results could provide a theoretical scientific basis for wood utilization and early prediction of wood properties (Mnghui, 1996). Using Postia placenta and Trametes 
versicolor as the testing models, the decay of $C$. lanceolata wood showed $34 \%$ of mass loss, indicating that it should be classified as slightly durable or non-durable wood and would be classified as moderately resistant (Xing et al., 2005). Testing specimens with different ratios of heartwood thickness to sapwood thickness under radial compression at different compression speeds revealed a consistent tendency of the density distribution and the copper retention along the thickness direction, and showed the layers with higher density having smaller volumes of void areas, and more chemicals absorbed and fixed than in the higher copper retentions (Mao et al., 2009). Using vacuum impregnation and characterizing with $\mathrm{x}$-ray powder diffraction (XRD), scanning electron microscope (SEM), Fourier transform infrared spectroscopy (FTIR), and thermogravimetrydifferential termal analysis (TG-DTA) analyses, the XRD analysis of $C$. lanceolata wood indicated that the wood crystallinity of wood/MMT nanocomposites (WMNC) decreased, the montmorillonite (MMT) exfoliated, and some nano silicate layers entered into the non-crystallized microfibrillar region of the wood cell wall (Lü \& Zhao, 2008). To establish the method of evaluating wood mechanical properties by acoustic nondestructive testing of standing trees and logs of a $C$. lanceolata plantation, a study concluded that longitudinal vibration may be the most precise and reliable technique to evaluate the mechanical properties of logs among three acoustic nondestructive methods (Yin et al., 2010). Furthermore, literature also has recoded that the red-heart wood ratio of $\mathrm{C}$. lanceolate ranges from $50.5 \%$ to $80 \%$ in mature forests (Deng et al., 2018; Li et al., 2019b).

\section{Chemicals and essential oils of C. lanceolata}

Studies of the chemical composition of substances extracted from $C$. lanceolata have been undertaken for several decades (Zhou et al., 1997). A recent study of the chemical composition and olfactory description of the essential oil of $C$. lanceolata showed the main compounds in its oil included cedrol $(26.3 \%), \alpha-$ terpineol (24.1\%), and camphor (7.0\%) (Schmidt et al., 2016). The main constituents of wood essential oil extracted from C. konishii Hayata were cedrol $(53.03 \%)$ and $\alpha$-pinene $(25.57 \%)$; and the constituents of leaf essential oil were $\alpha$ pinene $(34.89 \%), p$-cymene $(16.66 \%)$, and $\gamma$ muurolene (11.35\%) (Cheng et al., 2013). Obtained by steam distillation, the yield of essential oil from $C$. konishii Hayata in Vietnam was $0.18 \%$ from leaves and $0.21 \%$ from wood, while the major essential constituents of these two samples oils from leaves and wood, respectively, were: $\alpha$-cedrol (30.6\% and $23.5 \%$ ), $\beta$-eudesmol (25.4\% and $0.8 \%$ ), (E)-nerolidol $(5.4 \%$ and $12.5 \%), \gamma$-eudesmol $(10.9 \%$ and $11.2 \%)$, and $\beta$-caryophyllene $(0.5 \%$ and $9.5 \%)$ (Nguyen Danh Hung et al., 2017).

The essential oil of $C$. lanceolata, even at low concentrations, presented fair antifungal activities against two white-rot fungi, Trametes versicolor and Irpex lacteus, and two brown-rot fungi, Postia placenta and Gloeophyllum trabeum. The oil's phenols and antifungal compounds also played a role in resistance to wood decay (Wang et al., 2011).

In addition, crude alcoholic plant extract (APE) from C. lanceolata was also tested and showed the presence of proteins $\left(17.7 \mathrm{mg} \mathrm{mL}^{-1}\right)$, flavonoids $\left(2.35 \mathrm{mg} \mathrm{mL}^{-1}\right)$, and phenols $(0.19 \mathrm{mg}$ $\mathrm{mL}^{-1}$ ). This crude APE from C. lanceolata was found to be useful against Klebsiella pneumoniae with a maximum observed zone of clearance being $23.6 \mathrm{~mm}$, while the MIC (minimum inhibitory concentration) value was $0.36 \mathrm{mg} \mathrm{mL}^{-1}$ among the selected bacterial strains. This makes it a potential source of natural antioxidants as well as a strong antimicrobial agent with high protein, flavonoid, and phenolic contents (Jyoti et al., 2018). Essential oils and ethanolic extracts from $C$. konishii Hayata were investigated for use against $A$. aegypti and $A$. albopictus, and the results suggested their effective constituents served as a potential ecofriendly mosquito larvicide against dengue mosquitoes (Cheng et al., 2013).

\section{Discussion for big timber production with Samoc}

In 2007, the Vietnamese government issued a strong policy document (Vietnam Gov, 2007), 
which was revised and improved in 2011 (Vietnam Gov, 2011), to encourage the planting of trees for big timber production throughout the period 2007-2015. An enhanced policy has since been issued, providing continuous approval of a program for sustainable forestry development during the period 2016-2020 with a target to develop 290,000 ha of big timber plantations (Vietnam Gov, 2017). However, there have been a number of challenges regarding domestic big timber development (e.g. small upland households with small and fragmental land; low household incomes, investment, and credit access; weak collaboration for timber production value chains; poor infrastructure for forestry; and weak technologies of silviculture (Bui, 2018)).

Regarding the market demand for big timber, the wood processing sector of Vietnam has been rapidly expanding and has required substantial imports of primary wood material, especially hardwoods, from over 100 countries. In 2018, about 10 million cubic metres of timber worth 2.34 billion USD market-value was imported by processing industries (Itto, 2019), however, only about $25 \%$ or 2.35 million cubic metres of roundwood worth 710.5 million USD was provided to domestic industries (Itto, 2020). Furthermore, UN Comtrade reported that wood sourced for import by Vietnam was always a high risk (Norman, 2016). However, the domestic capacity for the provision of big timber in Vietnam is extremely small, which is a serious problem for sustainable forestry development (e.g. big timber plantations have not yet developed sufficiently to meet the target, with only about 40,000 cubic metres of legal raw timber being provided by domestic forests (VOV, 2017)). In addition, plant species currently available in big timber plantations in Vietnam are mostly Eucalyptus and Acacia, which are introduced species (MARD, 2018). Many potential native plant species for big timber are still undergoing research, such as the six timber native species legally approved by the Ministry of Agriculture and Rural Development (MARD), namely Dipterocarpus alatus, Magnolia conifera, Cunninghamia lanceolata, Hopea odorata, Melaleuca cajuputi, and Pinus kesiya (MARD, 2018), and suggested species including Azadirachta exselsa, Canarium album, Cinnamomum bejolghota, Cinnamomum parthenoxylon, Lithocarpus fissus, Michelia mediocris, and Prunus arborea (Tran Van Con, 2013).

Before the 1990s, a large area of natural $C$. lanceolata was explored for big timber in the Northern regions of Vietnam, but this species was not found to be planted widely. Currently, research results and published literature regarding $C$. lanceolata are very poor, with only a few literature mentions of its flora classification and distribution (Thai Van Trung, 1970; Phan et $a l ., 2017$ ), silviculture practices (e.g. standard processes of $C$. lanceolata afforestation) (MARD, 2002), essential oil characteristics (Nguyen Danh Hung et al., 2017), and seedling and nursery techniques (Ho \& Tran, $2017 \mathrm{a}, \mathrm{b}$; Nguyen et al., 2017b).

A few existing plantations of $C$. lanceolata have been established in places where Eucalyptus and Acacia cannot be grown because of low winter temperatures and poor soil fertility. However, the growth of $C$. lanceolata in these places is not as fast as its potential growth rate (e.g. the DHB of 20-year-old trees of $C$. lanceolata planted in household plots ranges from $15-20 \mathrm{~cm}$ (personal record)). However, the evidence reviewed above shows that $C$. lanceolata could be utilized in a range of applications, for small or large timber plantations, mixed plantations, and agroforestry. Therefore, the cultivation of this species for big timber production should be based on best silviculture practices, which ensure good seed quality, suitable stand density, appropriate fertilization, and a thinning strategy. It could also be planted at lower altitudes or in warmer regions, with consideration given to the possible trade-off between likely better growth conditions, and possibly poorer seed production.

\section{Conclusions}

Based on the above reviewed evidence regarding $C$. lanceolata, there are many advantages in using this tree for timber production. C. lanceolata is a naturally big- 
stemmed tree with a wide distribution, especially when its introduced distribution is considered. While it tolerates infertile soil, strong wind, and cold temperatures, it also grows better in warmer temperatures. It is good at naturally self-thinning and tolerates shade, making it appropriate to grow in high density and/or in mixed plantations. Its growth seems not strongly dependent on altitude (excepting for seed production). It is a potentially multi-purpose plant for big/small timbers, and for essential oils - a natural and safe non-timber forest product for human usage. However, similar to other native species, there has not yet been much interest in $C$. lanceolata as a plantation species in Vietnam.

\section{Acknowledgments}

We gratefully thank Dr. Katrina Hergstrom and Dr. Michael Moller from the Australian volunteers program of the Australian Embassy Vietnam for their editorial assistance.

\section{References}

Bi J., Blanco J. A., Seely B., Kimmins J. P., Ding Y. \& Welham C. (2007). Yield decline in Chinese-fir plantations: a simulation investigation with implications for model complexity. Canadian Journal of Forest Research. 37(9): 1615-1630.

Bui C. N. 2018. Overview of policy and opportunity of big timber planting development in Vietnam. Vietnam Administration of Forestry, MARD (in Vietnamese).

Cao J., Lin T.-C., Yang Z., Zheng Y., Xie L., Xiong D. \& Yang Y. (2020). Warming exerts a stronger effect than nitrogen addition on the soil arbuscular mycorrhizal fungal community in a young subtropical Cunninghamia lanceolata plantation. Geoderma. 367: 114273.

Chen L.-C., Wang H., Yu X., Zhang W.-d., Lü X.-T. \& Wang S.-L. (2017). Recovery time of soil carbon pools of conversional Chinese fir plantations from broadleaved forests in subtropical regions, China. Science of The Total Environment. 587-588: 296-304.

Cheng S. S., Lin C. Y., Chung M. J., Liu Y. H., Huang C. G. \& Chang S. T. (2013). Larvicidal activities of wood and leaf essential oils and ethanolic extracts from Cunninghamia konishii Hayata against the dengue mosquitoes. Industrial Crops and Products. 47: 310315.

Cheng X.-p., Kiyoshi U., Tsuyoshi H. \& Shao P.-y. (2011). Height growth, diameter-height relationships and branching architecture of Pinus massoniana and
Cunninghamia lanceolata in early regeneration stages in Anhui Province, eastern China: effects of light intensity and regeneration mode. Forestry Studies in China. 13(1): 1-12.

Chung J. D., Lin T. P., Tan Y. C., Lin M. Y. \& Hwang S. Y. (2004). Genetic diversity and biogeography of Cunninghamia konishii (Cupressaceae), an island species in Taiwan: a comparison with Cunninghamia lanceolata, a mainland species in China. Molecular Phylogenetics and Evolution. 33(3): 791-801.

Deng H. W. X., Zhang Y., Wei X., Wang G., Zhou B., Xiang W. \& Zhu N. (2018). Cunninghamia lanceolata variant with red-heart wood: a mini-review. Dendrobiology. 79: 156-167.

Farjon A (2010). A Handbook of the World's Conifers. Vol. 1 \& 2. E. J. Brill, Leiden \& Boston. 1112 pp. Retrieved from https://www.gbif.org/species/5284278 on December 10, 2020.

Fung L. E. (1993a). Cunninghamia lanceolata (Chinese fir). A study of its potential as a commercial plantation species in New Zealand $\mathrm{PhD}$, University of Canterbury.

Fung L. E. (1993b). Wood properties of New Zealandgrown Cunninghamia lanceolata New Zealand Journal of Forestry Science. 23(3): 324-338.

He Y., Wang Q., Wang S. \& Yu X. (2007). Characteristics of carbon and nitrogen of soil microbial biomass and their relationships with soil nutrients in Cunninghamia lanceolata plantations. Frontiers of Forestry in China. 2(3): 266-271.

Heinsdijk D. 1972. Forest in Southern Brazil. Rio de Janiero, Brazil: Instituto Brasileiro de Desenvolvimeto Florestal.

Ho N. S. \& Tran T. H. G. (2017a). Impacts of seed stipulation methods on the germination of Cunninghamia konishii Hayata. Science and Technology Journal of Agriculture and Rural Development. Special of Variety Issue (2): 206-212.

Ho N. S. \& Tran T. H. G. (2017b). Study on seed processing and storage techniques for Cunninghamia konishii Hayata. Science and Technology Journal of Agriculture and Rural Development. 22: 85-92.

ITTO (2019). Tropical timber market report International Tropical Timber Organisation (ITTO).

ITTO (2020). Biennial review statistics. Retrieved from https://www.itto.int/biennal_review/?mode=searchdat a on April 22, 2020.

Jiang J., Lu J., Ren H. \& Long C. (2010). Predicting the flexural properties of Chinese fir (Cunninghamia lanceolata) plantation dimension lumber from growth ring width. Journal of Wood Science. 56(1): 15-18.

Jyoti P., Meena K. R., Sharma A., Kapoor R., Sharma T. \& Kanwar S. S. (2018). Anti-microbial and Anti-oxidant Properties of Cunninghamia lanceolata. Insight Pharmaceutical Sciences. 8(1): 1-7.

Kang B., Liu S., Zhang G., Chang J., Wen Y., Ma J. \& Hao W. (2006). Carbon accumulation and distribution in 
Pinus massoniana and Cunninghamia lanceolata mixed forest ecosystem in Daqingshan, Guangxi, China. Acta Ecologica Sinica. 26(5): 1320-1327.

Kang H., Seely B., Wang G., Cai Y., Innes J., Zheng D., Chen P. \& Wang T. (2017). Simulating the impact of climate change on the growth of Chinese fir plantations in Fujian province, China. New Zealand Journal of Forestry Science. 47(1): 1-20.

Li R.-S., Yang Q.-P., Zhang W.-D., Zheng W.-H., Chi Y.G., Xu M., Fang Y.-T., Gessler A., Li M.-H. \& Wang S.-L. (2017). Thinning effect on photosynthesis depends on needle ages in a Chinese fir (Cunninghamia lanceolata) plantation. Science of The Total Environment. 580: 900-906.

Li R., Han J., Guan X., Chi Y., Zhang W., Chen L., Wang Q., Xu M., Yang Q. \& Wang S. (2020). Crown pruning and understory removal did not change the tree growth rate in a Chinese fir (Cunninghamia lanceolata) plantation. Forest Ecology and Management. 464: 118056.

Li R., Zheng W., Yang Q., Zhang W., Chi Y., Wang P., Xu M., Guan X., Chen L., Wang Q. \& Wang S. (2019a). The response of soil respiration to thinning was not affected by understory removal in a Chinese fir (Cunninghamia lanceolata) plantation. Geoderma. 353: 47-54.

Li Y., Deng X., Zhang Y., Huang Y., Wang C., Xiang W., Xiao F. \& Wei X. (2019b). Chemical Characteristics of Heartwood and Sapwood of Red-Heart Chinese Fir (Cunninghamia lanceolata). Forest Products Journal. 69(2): 103-109.

Liao Y., Fan H., Wei X., Wu J., Duan H., Fu X., Liu W., Wang H., Zhan X., Tang P. \& Li F. (2019). Competition increased fine root biomass in Chinese fir (Cunninghamia lanceolata) plantations in Subtropical China. Forest Ecology and Management. 435: 151-157.

Liu B., Liu Q., Daryanto S., Ma X., Guo S., Wang L. \& Wang Z. (2018). Seedling emergence and early growth of Chinese fir under different light levels and seed positions: implications for natural regeneration. Canadian Journal of Forest Research. 48(9): 10341041.

Lü W. \& Zhao G. (2008). Structure and characterization of Chinese fir (Cunninghamia lanceolata) wood/MMT intercalation nanocomposite (WMNC). Frontiers of Forestry in China. 3(1): 121-126.

Lu Y., Coops N. C., Wang T. \& Wang G. (2015). A Process-based approach to estimate Chinese Fir (Cunninghamia lanceolata) distribution and productivity in Southern China under climate change. 6(2): 360-379.

Mao J., Cao J.-Z. \& Zheng X. (2009). Effect of compression on the liquid absorption of Chinese fir wood with different heartwood-to-sapwood ratios. Forestry Studies in China. 11(3): 196-201.
MARD (2002). Sector standard 04-TCN-66-2002 - Process of afforestation of Sa Moc forest, issued together with Decision No. 4895/QD-BNN-KHCN of November 11, 2002 of the Ministry of Agriculture and Rural Development. Ministry of Agriculture and Rural Development.

MARD (2018). Circular 30/2018/TT-BNNPTNT list of major forest tree species recognition of cultivars cultivar sources. In: Development, M. O. a. a. R. (ed.) (in Vietnamese).

Minghe L. \& Ritchie G. A. (1999). Eight hundred years of clonal forestry in China: I. traditional afforestation with Chinese fir (Cunninghamia lanceolata (Lamb.) Hook.). New Forests. 18(2): 131-142.

Mnghui G. (1996). Variation pattern of wood properties of natural Cunninghamia lanceolata. Journal of Northeast Forestry University. 7(2): 56-59.

Nguyen Danh Hung, Nguyen Thanh Chung, Phan Thi Quynh Nga, Nguyen Xuan Truong and Do Ngoc Dai (2017). Biological characteristics and volatile oil constituents of Cunninghamia konishii Hayata in $\mathrm{Pu}$ Hoat Nature Reserve, Nghe An Province. The $7^{\text {th }}$ National Conference on Ecology and Biological Resources.. 1207-1213 (in Vietnamese).

Nguyen Dinh Vo (2017). Oily Samu - A heritage tree of Nghe An Provnce in the top ten of world giant trees. http://nghean.gov.vn/ (in Vietnamese).

Nguyen T. T. H., Ho N. S., Tran T. H. G. \& Dang K. T. (2017b). Testing results of some chemical pesticides used on Cunninghamia konishii Hayata nursery period in Ha Giang Province Science and Technology Journal of Agriculture and Rural Development. 13: 124-128.

Niu D., Wang S. \& Ouyang Z. (2009). Comparisons of carbon storages in Cunninghamia lanceolata and Michelia macclurei plantations during a 22-year period in southern China. Journal of Environmental Sciences. 21(6): 801-805.

Norman M. (2016). Trends in timber product exports and imports from Vietnam and the Mekong region. Forest Trends. Report in October 2016. Retrieved from https://www.forest-trends.org/wpcontent/uploads/imported/vietnam-and-mekongexport-and-import-trends__marigold-norman-foresttrends-pdf.pdf on December 3, 2019.

Pham V. T., Phan K. L., Averyanov L. V., Nguyen S. K. \& Nguyen T. T. H. (2013). Native conifers of Vietnam: Updated checklist 2013. Journal of Ecological Economy. 45: 33-45.

Phan K. L., Pham V. T., Phan K. L., Regalado J., Averyanov 1. V. \& Maslin B. (2017). Native conifers of Vietnam - a review Pakistan Journal of Botany. 49(5): 2037-2068.

Schlarbaum S. E. \& Tsuchiya T. (1984). The chromosomes of Cunninghamia konishii, C. lanceolata, and Taiwania cryptomerioides (Taxodiaceae). Plant Systematics and Evolution. 145(3): 169-181. 
Schmidt E., Huong L. T., Dai D. N., Thang T. D., Wanner J. \& Jirovetz L. (2016). Analysis and Olfactory Description of Four Essential Oils from Vietnam. 11(10): 1934578X1601101032.

Selvaraj S., Duraisamy V., Huang Z., Guo F. \& Ma X. (2017). Influence of long-term successive rotations and stand age of Chinese fir (Cunninghamia lanceolata) plantations on soil properties. Geoderma. 306: 127-134.

Sun H., Zhang J., Duan A. \& He C. (2011). Estimation of the self-thinning boundary line within even-aged Chinese fir (Cunninghamia lanceolata (Lamb.) Hook.) stands: Onset of self-thinning. Forest Ecology and Management. 261(6): 1010-1015.

Thai Van Trung (1970). Forest flora of Vietnam. Science and Technics Publishing House. p230. (in Vietnamese).

Tran Van Con (2013). Research on scientific, technological and socio-economic solutions to plant large, fastgrowing timber forests on bare land with poor forest and forest land properties. Vietnamese Academy of Forest Sciences. p245 (in Vietnamese).

Vietnam Gov (2007). Decision on a number of policies for development of production forests in the 2007-2015 period. Retrieved from https://thuvienphapluat.vn/van-ban/tai-nguyen-moitruong/Quyet-dinh-147-2007-QD-TTg-chinh-sachphat-trien-rung-san-xuat-giai-doan-2007-201555318.aspx on Socialist Republic of Vietnam Government Portal (in Vietnamese).

Vietnam Gov (2011). Decision amending and supplementing a number of articles of decision no. 147/2007/QD-TTG of September 10, 2007, on a number of policies for development of production forests during 2007-2015. Retrieved from https://thuvienphapluat.vn/van-ban/Tai-nguyen-Moitruong/Quyet-dinh-66-2011-QD-TTg-sua-doi-Quyetdinh-147-2007-QD-TTg-chinh-sach-phat-

132806.aspx on Socialist Republic of Vietnam Government Portal (in Vietnamese).

Vietnam Gov (2017). Decision approving target program for sustainable forestry development during 20162020 period. Retrieved from https://huvienphapluat.vn/van-ban/Tai-nguyen-Moitruong/Quyet-dinh-886-QD-TTg-2017-phe-duyetChuong-trinh-phat-trien-Lam-nghiep-ben-vung-20162020-352354.aspx on Socialist Republic of Vietnam Government Portal (in Vietnamese).

Vietnam Plant Data Center (2009). Introduction of Vietnam conifers: Cunninghamia konishii. Retrieved from http://www.botanyvn.com/?lg=en on November 11, 2019.

VOV (2017). Timber supply matters to Vietnam's wood industry. In: Vietnam, T. V. O. (ed.) (in Vietnamese).

Wadsworth F. H. (1997). Forest Production for Tropical America. U.S. Department of Agriculture, Forest Service. pp563.
Wang J., Li J., Li S., Freitag C. \& Morrell J. J. (2011). Antifungal activities of Cunninghamia lanceolata heartwood extractives. BioResources. 6(1): 606-614.

Wang Q., Wang S. \& Huang Y. (2008). Comparisons of litterfall, litter decomposition and nutrient return in a monoculture Cunninghamia lanceolata and a mixed stand in southern China. Forest Ecology and Management. 255(3): 1210-1218.

Wang Q., Wang S. \& Huang Y. (2009). Leaf litter decomposition in the pure and mixed plantations of Cunninghamia lanceolata and Michelia macclurei in subtropical China. Biology and Fertility of Soils. 45(4): 371-377.

Wang Q., Zhang W., Sun T., Chen L., Pang X., Wang Y. \& Xiao F. (2017). N and P fertilization reduced soil autotrophic and heterotrophic respiration in a young Cunninghamia lanceolata forest. Agricultural and Forest Meteorology. 232: 66-73.

WCSP (1827). World checklist of selected plant families: Cunninghamia lanceolata (Lamb.) Hook., Bot. Mag. 54: t. 2743 (1827).

WCSP (1908). World checklist of selected plant families: Cunninghamia konishii Hayata, Gard. Chron., ser. 3, 43: 194 (1908).

WCSP (1932). World checklist of selected plant families: Cunninghamia lanceolata var. konishii (Hayata) Fujita, Trans. Nat. Hist. Soc. Formosa. 22: 49, 476 (1932).

Wu H., Xiang W., Ouyang S., Xiao W., Li S., Chen L., Lei P., Deng X., Zeng Y., Zeng L. \& Peng C. (2020). Tree growth rate and soil nutrient status determine the shift in nutrient-use strategy of Chinese fir plantations along a chronosequence. Forest Ecology and Management. 460: 117896.

Xia Z.-C., Kong C.-H., Chen L.-C. \& Wang S.-L. (2015). Allelochemical-mediated soil microbial community in long-term monospecific Chinese fir forest plantations. Applied Soil Ecology. 96: 52-59.

Xing J.-q., Ikuo M. \& Wakako O. (2005). Natural resistance of two plantation woods Populus $\times$ canadensis cv. and Cunninghamia lanceolata to decay fungi and termites. Forestry Studies in China. 7(1): 36-39.

Xu H., Cao D., Feng J., Wu H., Lin J. \& Wang Y. (2016). Transcriptional regulation of vascular cambium activity during the transition from juvenile to mature stages in Cunninghamia lanceolata. Journal of Plant Physiology. 200: 7-17.

Xu Y., Du C., Huang G., Li Z., Xu X., Zheng J. \& Wu C. (2019). Morphological characteristics of tree crowns of Cunninghamia lanceolata var. Luotian. Journal of Forestry Research. DOI: 10.1007/s11676-019-00901-4.

Xue L., Hou X., Li Q. \& Hao Y. (2015). Self-thinning lines and allometric relation in Chinese fir (Cunninghamia lanceolata) stands. Journal of Forestry Research. 26(2): 281-290. 
Yang Y., Zhang X., Wang H., Fu X., Wen X., Zhang C., Chen F. \& Wan S. (2019). How understory vegetation affects the catalytic properties of soil extracellular hydrolases in a Chinese fir (Cunninghamia lanceolata) forest. European Journal of Soil Biology. 90: 15-21.

Yeh F. C., Shi J., Yang R., Hong J. H. \& Ye Z. (1994). Genetic diversity and multilocus associations in Cunninghamia lanceolata (Lamb.) Hook from The People's Republic of China. Theoretical and Applied Genetics. 88(3): 465-471.

Yin Y., Nagao H., Liu X. \& Nakai T. (2010). Mechanical properties assessment of Cunninghamia lanceolata plantation wood with three acoustic-based nondestructive methods. Journal of Wood Science. 56(1): 33-40.

Zhang J., Wang S., Feng Z. \& Wang Q. (2009). Stability of soil organic carbon changes in successive rotations of Chinese ffir (Cunninghamia lanceolata (Lamb.) Hook) plantations. Journal of Environmental Sciences. 21(3): 352-359.

Zhang X., Wang Z., Chhin S., Wang H., Duan A. \& Zhang J. (2020). Relative contributions of competition, stand structure, age, and climate factors to tree mortality of Chinese fir plantations: Long-term spacing trials in southern China. Forest Ecology and Management.
465: 118103.

Zhou L., Shalom A.-D. D., Wu P., Li S., Jia Y. \& Ma X. (2015). Litterfall production and nutrient return in different-aged Chinese fir (Cunninghamia lanceolata) plantations in South China. Journal of Forestry Research. 26(1): 79-89.

Zhou L., Sun Y., Saeed S., Zhang B. \& Luo M. (2020). The difference of soil properties between pure and mixed Chinese fir (Cunninghamia lanceolata) plantations depends on tree species. Global Ecology and Conservation. 22: e01009.

Zhou T., Jia X., Liao H., Peng S. \& Peng S. (2016). Effects of elevated mean and extremely high temperatures on the physio-ecological characteristics of geographically distinctive populations of Cunninghamia lanceolata. Scientific Reports. 6: 39187-39187.

Zhou X., Cheng C. \& Roshchin V. J. L. H. Y. G. (1997). Study on the chemical composition of substances extracted from the green crown of Cunninghamia lanceolata Hook. 17: 55-60.

Zhu G., Hu S., Chhin S., Zhang X. \& He P. (2019). Modelling site index of Chinese fir plantations using a random effects model across regional site types in Hunan province, China. Forest Ecology and Management. 446: 143-150. 